\title{
A condição de servente na construção civil
}

\author{
Paulo Henrique Faleiro dos Santos ${ }^{1}$ e Vanessa Andrade de Barros ${ }^{2}$ \\ Faculdade de Filosofia e Ciências Humanas da \\ Universidade Federal de Minas Gerais (Belo Horizonte, MG)
}

Compreender as raízes e o contexto em que é gerada e reproduzida a discriminação da categoria dos serventes na construção civil, bem como suas implicações psicossociais. Esse foi o objetivo norteador de uma investigação desenvolvida através de um estudo de caso, cujos resultados e análises dão corpo ao presente artigo. $\mathrm{O}$ trabalho se inscreve nas chamadas Clínicas do Trabalho, na perspectiva da psicossociologia do trabalho. Tomou-se como campo do estudo uma empresa privada de pequeno porte do ramo da construção civil, situada na Região Metropolitana de Belo Horizonte, MG. A pesquisa foi dividida em três etapas: (a) estudos preliminares; (b) observações ergonômicas e entrevistas; e (c) análise das entrevistas e estruturação do texto. Constatou-se uma marcante contradição entre os discursos dirigidos ao servente quando falam de sua atividade a partir do senso comum e aqueles que partem da vivência e da análise do trabalho real desses profissionais. Além disso, revelou-se que a condição de servente encarna um conjunto de características assimiladas como negativas, que dificultam a formação de uma autoimagem e de uma identidade positivas por parte daqueles que são por ela marcados. Identificou-se também que a discriminação da categoria exerce importante função política (controle social) através do enfraquecimento ou mesmo anulação da coesão e organização coletivas. O estudo denuncia a coexistência dos mais sofisticados mecanismos de produção e a sujeição de seres humanos a relações/situações de vida e trabalho humilhantes e/ou degradantes, contradição classificada como ética e moralmente insustentável. Ele sugere ainda que a negligência de investimentos focados no desenvolvimento humano, no contexto de trabalho, mostra-se contraproducente, mesmo que sob a lógica do lucro. Finalmente, as considerações apontam para a necessidade de criação de outro conceito de trabalho em nossas sociedades.

Palavras-chave: Serventes, Construção civil, Discriminação, Clínicas do trabalho.

\section{The servant condition in construction}

To understand the roots and the context in which discrimination at servants (attendant laborers) in construction is generated and reproduced, as well as their psychosocial implications. This was the guiding objective of a research developed through a case study. It's results and analysis embodies the present article. The work fits in the so-called Clinics of Labor, at the labor psychosociology perspective. The field of study was a small private company in the business of construction, situated in the metropolitan area of Belo Horizonte, Minas Gerais State, Brazil. The research was divided into three stages: (a) preliminary studies, (b) ergonomic observations and interviews and (c) categorization of verbalization and structuring of the text. It was found a striking contradiction between the discourse addressed to the servant when speaking of his activity from the common sense and the speeches that come from analysis of the actual work of these professionals. Besides that, it was revealed that the condition embodies a set of characteristics treated as negative, which hinder the formation of a self-image and a positive identity by those who are marked by it. It was also found that the category of discrimination has an important political function (social control) by weakening and breaking down cohesion and collective organization. The study reveals the coexistence of sophisticated mechanisms of construction production and the placing of human beings into humiliating and/or degrading conditions, which is classified as ethically and morally untenable. It also suggests that the neglect of investments focused on human development, in the work context, reveals to be counterproductive, even under the profit logic. Finally, the considerations point to the need of overcoming the old social order and to create a new concept of work in our societies.

Keywords: Servant (attendant laborer), Construction business, Discrimination, Labor clinics.

\footnotetext{
1 Mestre em Psicologia pela UFMG.

2 Professora do Programa de Pós-graduação em Psicologia da UFMG. Laboratório de Ensino, Pesquisa e Extensão em Psicologia do Trabalho (LabTrab).
} 


\section{Introdução}

Então, tipo assim, eu queria entender por que essa tão discriminação que tem com o servente. Eu pelo menos não entendo. Porque nós, todo mundo, tanto faz encarregado, principalmente, igual eu, sou pedreiro, precisa do servente, né. Porque o pedreiro sem o servente ele não faz nada. Ele faz, mas é menos do que com o servente. É isso que eu queria até, nesse caso, até eu mesmo queria entender por que dessa discriminação que tem contra o servente (pedreiro).

$\mathrm{O}$ pilares que sustentam o presente trabalho estão fincados bem aí, no incômodo provocado pela situação excludente e ambivalente tão bem apresentada na fala do pedreiro Zezinho ${ }^{3}$. Ao ingressar como psicólogo social em canteiros de obras, em abril de 2007, o que logo chamou a minha atenção foi observar uma desconfortável contradição. Aquela existente entre o que eu percebia como um lugar marginal ou um "não lugar", atribuído dentro daquele campo e não apenas nele - aos operários tidos como menos qualificados, os serventes, e a importância de sua atividade no processo produtivo da construção civil.

São muitos os estereótipos depreciativos lançados a esses trabalhadores, depositando nos indivíduos a responsabilidade exclusiva pela situação de vida tantas vezes precária, além de desviar a atenção daquilo que Jacques Duraffourg delata com transparência e lucidez:

As mudanças importantes sobre as quais ninguém quer falar referem-se ao conteúdo e às condições de trabalho. Dizer que "os jovens são preguiçosos e não querem trabalhar", que "as pessoas resistem às mudanças e elas não querem sair de onde estão!": isso não é uma argumentação. Na melhor das hipóteses é uma maneira de se recusar a ver a realidade e, na pior, é uma desonestidade. (...) Tenho mesmo a tendência de inverter o discurso: não é um drama que pessoas sejam forçadas a aceitar situações em que perdem sua saúde ao serem obrigadas a trabalhar? (...) Quando eu encontro essas pessoas na minha vida profissional, elas dizem que esperam só uma coisa, poder trocar de emprego: quem, realmente, resiste à mudança? (Duraffourg, Durrive \& Duc, 2007, p. 54)

A reflexão do ergonomista aponta, entretanto, para um cenário preocupante também àqueles que resistem a enxergar o real. Tal cenário já se faz presente no mundo globalizado e não permite ser despercebido tanto pela iniciativa pública quanto pela privada no Brasil, em vários setores produtivos e, com efeito, no da construção civil e infraestrutura. Trata-se da escassez de profissionais disponíveis para suprir a crescente demanda de produção que, segundo os indicadores econômicos e a projeção dos especialistas (Almeida, 2010), se fará presente pelo menos ao longo da próxima década.

A classe de operários no setor é subdividida em três níveis hierárquicos definidos em função de capacitação técnica: servente (ou ajudante), semioficial (ou meio oficial) e oficial. A categoria dos serventes encontra-se, portanto, no polo inferior de atribuição de status profissional, sendo caracterizada pelos maiores níveis de precariedade, heteronomia e baixa valorização social, vinculados às tarefas que lhe são atribuídas e aos sujeitos que as realizam. Ainda assim, trata-se da categoria que reúne o maior contingente de operários em uma obra.

Mas o que se encontra por trás, ao redor e no cerne da discriminação, da recusa e da vivência da condição servente? Como reage subjetiva e socialmente o sujeito que habita ou evita habitar esse "não lugar"? Trata-se de fato de um "não lugar"? E que lugar ocupa o trabalho na organização da sociabilidade desses sujeitos (modos de vida, escolhas, identidade, valores)? O presente artigo sustenta-se em parte significativa dos resultados e das discussões de uma pesquisa impulsionada por essas e outras inquietações, nascidas, por sua vez, do contato com o dia a dia dos serventes. Compreender as raízes e o contexto em que é gerada e reproduzida "essa tão discriminação que tem contra o servente", bem como suas implicações 
psicossociais, foi a motivação propulsora do estudo que, somente ao longo de seu próprio desenvolvimento, se permitiu desvelar como objetivo geral. Focalizaremos aqui a condição de servente na construção civil, apresentando o contexto de discriminação, desvalorização, humilhação e de assédio psicossocial vivenciado pela categoria e abordando suas implicações individuais, sociais e políticas, tal como nos ensinam a Psicossociologia do Trabalho (Lhuilier \& Clot, 2010) e a Ergologia (Schwartz \& Durrive, 2009).

\section{A pesquisa}

Para a realização da pesquisa, lançamos mão da opção metodológica do estudo de caso:

Uma situação de trabalho contém as questões da sociedade. Inversamente, pela maneira como se trabalha, cada um toma posição nestes debates da sociedade e os recompõe na sua escala (Schwartz, Durrive \& Duc, 2007a, p. 31).

Segundo Yin (1989, apud Bressan, 2000), o estudo de caso é "uma inquirição empírica que investiga um fenômeno contemporâneo dentro de um contexto da vida real", em que comportamentos relevantes não podem ser manipulados, mas é possível fazer observações diretas e entrevistas sistemáticas. Caracteriza-se pela "capacidade de lidar com uma completa variedade de evidências - documentos, artefatos, entrevistas e observações". Alguns autores afirmam que "o estudo de caso não é uma metodologia específica, mas uma forma de organizar dados preservando o caráter único do objeto social em estudo" (Goode \& Hatt, 1952, apud Coutinho \& Chaves, 2001). A escolha metodológica submete-se às características específicas do objeto focalizado, às afinidades teórico-conceituais do pesquisador e, não menos, à consciência dos limites estabelecidos pela envergadura característica de uma dissertação de mestrado, contexto acadêmico em que a pesquisa foi desenvolvida.

Tomamos como campo do estudo uma empresa privada de pequeno porte do ramo da construção civil, situada na Região Metropolitana de Belo Horizonte (RMBH), Estado de Minas Gerais. A construtora contava, no momento da pesquisa, com 392 funcionários diretos, isto é, formalmente registrados em seu quadro de efetivos. Desses, 292 (74,5\%) eram operários (oficiais, meio oficiais ou serventes). Na categoria de operários, dos 292 que compunham o grupo, 106 (36\%) eram oficiais (pedreiros, carpinteiros, armadores, operadores de máquinas, montadores e eletricistas), 28 (10\%) meio oficiais e 158 (54\%) serventes. Nota-se que a categoria dos serventes se apresenta como significativamente mais numerosa nos canteiros de obra da empresa. Em relação a todo o quadro de funcionários (392), os serventes representavam no momento $40,3 \%$.

A encomenda de intervenção enunciada pela diretoria da empresa era a de promover a melhoria das condições de vida dos trabalhadores através da doação de casas próprias a funcionários de nível operário, definindo-se critérios e métodos para isso. Através da frequentação do canteiro de obras em busca de conhecer a realidade de trabalho, bem como de discussões com os trabalhadores e com a direção da empresa, conseguimos transformar uma encomenda vinda da alta hierarquia, sem a participação dos trabalhadores, em uma demanda. Isso significou envolver trabalhadores e direção em um projeto comum de pesquisa/intervenção que visava compreender as situações de trabalho para transformá-las (Lhuilier \& Clot, 2010; Carreteiro \& Barros, 2010).

A primeira fase do trabalho teve início em abril de 2007. Além de observações situacionais do dia a dia de trabalho e comunicações informais junto aos operários, formulamos um roteiro de orientação para uma "conversa" realizada individualmente com os funcionários diretos (formalmente registrados na construtora) e indiretos (funcionários de empreiteiros 
terceirizados) presentes em uma determinada obra. Ao todo, no período de julho a dezembro de 2007, foram trabalhados os dados de 79 (setenta e nove) entrevistas, contemplando a totalidade dos operários efetivos do período, sendo 43 (quarenta e três) funcionários da construtora e 36 (trinta e seis) da empreiteira terceirizada. Participaram das entrevistas os cargos de servente (33), pedreiro (10), armador (13), carpinteiro (14), almoxarife (1), eletricista (1), encarregado (3), mestre de obras (1), vigia (2) e técnico de segurança (1). A ordem das entrevistas foi aleatória, levando em consideração exclusivamente a disponibilidade dos entrevistados no momento da entrevista, visando impactar o mínimo possível o andamento da obra. A aplicação da primeira metade das entrevistas, que duravam em média 2 horas e 30 minutos cada, foi feita pelo pesquisador, enquanto que, para as demais, pude contar com a valiosa participação de duas estagiárias de psicologia. Todas elas foram realizadas durante o horário de trabalho dos entrevistados, com a anuência da empresa. $O$ roteiro elaborado apresentou questões focadas em quatro contextos (pessoal, familiar, moradia e comunitário), tendo investigado aspectos variados, tais como idade, escolaridade, idade em que iniciaram a atividade laboral, a primeira atividade exercida, sonhos, desejos, hábitos, nível de satisfação/insatisfação em relação à situação de vida, composição familiar, rendimento familiar, escolaridade dos filhos, condições de moradia, aspectos comunitários, dentre outros. Essa aproximação da realidade de vida e trabalho dos operários - bem como o meu retorno à academia e encontro com o pensamento de representantes das Clínicas do Trabalho e da Ergologia - exigiu a explicitação de um posicionamento: o favorecimento da melhoria das condições de vida dos trabalhadores não deveria partir de outro ponto que não o investimento na melhoria das condições de trabalho. Caso contrário, a iniciativa se mostraria míope e assumiria uma contradição recorrente: através dos discursos ideológicos e publicitários de Responsabilidade Social Empresarial, cuidar de fora e ignorar a realidade a ser transformada do lado de dentro dos tapumes. Ainda na primeira etapa do estudo, iniciamos a revisão bibliográfica acerca do trabalho operário na construção civil brasileira e a pesquisa documental, compilando dados diversos acerca do setor, informações que se mostraram imprescindíveis para a caracterização geral do campo sobre o qual, então, nos debruçamos.

A segunda fase da pesquisa foi composta por observações de cunho ergonômico da atividade dos serventes e três entrevistas semiestruturadas realizadas em grupo. A participação nas entrevistas em grupos foi espontânea. Contando com a autorização da empresa, após exposição de seus objetivos e condições, convidamos abertamente todo o grupo de funcionários de uma obra que ocupavam ou já haviam ocupado a categoria de servente a participar, de forma facultativa, da primeira entrevista, no horário de trabalho. Dispuseram-se a participar 26 funcionários, sendo 13 serventes, 9 pedreiros, 1 operador de máquinas, 1 meio oficial e 2 encarregados (um de elétrica e um de armação). A provocação inicial utilizada para disparar as verbalizações foi: "falem-me sobre o trabalho do servente". As colocações do pesquisador se fizeram presentes no sentido de solicitar esclarecimentos, mediar as manifestações, manter o foco da discussão no trabalho do servente e, ocasionalmente, também participar da discussão com colocações advindas das observações ergonômicas da atividade de trabalho da categoria. É importante mencionar que mesmo os participantes com funções distintas dos serventes haviam pertencido à categoria na fase inicial de sua carreira profissional. Assim, a discussão em grupo propiciou a expressão, a troca e a produção de saberes, ideias e opiniões acerca do trabalho dos serventes entre profissionais em diferentes etapas do desenvolvimento profissional na construção civil. Visando maximizar a participação dos participantes, o grupo inicial foi dividido em dois subgrupos, sendo realizada uma nova entrevista com cada. Assim, a segunda entrevista contou com a participação de 12 trabalhadores (sendo 6 serventes, 4 pedreiros, 1 meio oficial e 1 encarregado de armação). A entrevista com o Subgrupo B contou com 11 trabalhadores (sendo 4 serventes, 5 pedreiros, 1 operador de máquinas e 1 encarregado de elétrica). 
A terceira e última fase da pesquisa compreendeu a organização do material obtido através das entrevistas grupais em categorias de análise, bem como a estruturação dos capítulos da dissertação.

\section{O trabalho do servente}

\section{[...] servente é muito discriminado, porque não é profissão, é sofrimento (servente).}

Há certo consenso de que o desenvolvimento tecnológico na construção civil aliviou o serviço pesado designado aos operários, em especial aos serventes. Entretanto, nota-se que determinadas posturas organizacionais no setor não acompanharam a evolução alcançada pela tecnologia aplicada aos equipamentos. A fase inicial de mobilização do canteiro de obras, por exemplo, é comumente caracterizada pela precariedade das condições de trabalho e convivência (vestiários, sanitários, refeitório). Tivemos a oportunidade de presenciar serventes e outros operários carregando latas de concreto nos ombros para o enchimento de pilares no terceiro andar de uma obra, fase em que o elevador de carga e a grua (guindaste) ainda não haviam sido locados. Como o concreto tem um tempo limitado de validade entre a usinagem e a aplicação, chama a atenção a correria e o nível de esforço e desgaste exigido dos trabalhadores para a execução da atividade.

Observamos com mais atenção a atividade de um servente escalado para, no contexto descrito, receber dos colegas todas as latas de concreto e transferir seu conteúdo para o preenchimento das formas de um pilar. Ele se posiciona em uma plataforma montada sobre um andaime, a 2 metros de altura da laje, bem na extremidade desta, a uma altura de aproximadamente 8 metros da base do prédio. As latas são colocadas por outro servente no tablado de madeirite sobre o qual ele se encontra. Um terceiro servente é responsável por levantar cada lata do chão, que tem o peso de $45 \mathrm{~kg}$, e passá-la para o primeiro despejar o concreto dentro da forma. A lata é por ele girada na altura da sua cabeça, sendo encaixada por entre as ferragens do pilar. O trabalhador bate a lata virada na forma para que o concreto remanescente se solte do fundo da lata. A lata vazia é colocada no chão e outra lata cheia já chega às suas mãos. $\mathrm{O}$ servente mal tem tempo para tomar fôlego e observar a longa fila de colegas com latas nos ombros, latas que ainda passarão por suas mãos. Nesse processo, uma boa quantidade de concreto respinga para todos os lados, atingindo o ambiente, a roupa, braços e também o rosto dos trabalhadores. Encontra-se ao seu lado um quarto operário, este um oficial, responsável por "vibrar o concreto", isto é, introduzir na massa já despejada dentro da forma do pilar um aparelho vibrador necessário para o correto assentamento do concreto e a prevenção da formação de bolhas de ar. Esse aparelho produz um ruído incômodo, alto e constante. Somase ao contexto a indumentária exigida ao funcionário. Trata-se dos EPIs (Equipamentos de Proteção Individual), que promovem considerável desconforto. $\mathrm{Na}$ atividade observada, o servente utilizava capacete, uniforme (calça e camisa $67 \%$ poliéster e $33 \%$ viscose, um material pesado, quente e resistente), botas de PVC ("sete léguas", material impermeável, de cano longo), cinto de segurança (que pesa entre $2 \mathrm{~kg}$ e $3 \mathrm{~kg}$ e o prende ao andaime para evitar quedas), luvas de raspa (uma luva grande, que faz o trabalhador perder o tato fino e que não é impermeável) e protetores auriculares (peça de silicone introduzida no ouvido).

Para o enchimento do pilar em questão, foram necessárias cerca de 65 latas de concreto, totalizando $2.945 \mathrm{~kg}$ despejados na forma. Notamos que, a partir do terço final da atividade, o servente observado apresenta sinais claros de fadiga, como tremor nos braços e tensão na expressão facial. $\mathrm{O}$ encarregado permanece todo o tempo ao lado, supervisionando (e fiscalizando) o serviço. Finalizada a tarefa, pouco após ele descer do andaime, nos aproximamos 
e perguntamos como ele se sentia, demonstrando que o nível de esforço exigido na atividade havia chamado nossa atenção. O servente, 21 anos, magro, recém-chegado do interior, novato na construção civil e na empresa, relatou no momento que se sentia "normal", que a atividade era cansativa, mas "normal".

Nota-se na situação observada o nível de sobrepeso físico e pressão psíquica envolvidos na atividade. Para lidar com sua execução, o servente lança mão de si mesmo. Cada momento exige que escolhas sejam feitas e, com elas, riscos sejam assumidos. Nesse momento entra em cena o corpo-si, essa entidade um tanto enigmática que, segundo Schwartz (2007), atravessa tanto o intelectual quanto o corporal e o cultural, responsável pela gestão da distância entre o real e o prescrito na busca de tornar a situação "vivível". Nesse processo, o trabalhador gerencia as "infidelidades do meio" ${ }^{4}$, isto é, tudo aquilo que preenche essa distância, o que não haviam previsto, mas que lá está: a dor e fadiga nos braços, o incômodo da luva e dos demais equipamentos de segurança, as características físicas da forma de madeira e do posicionamento das ferragens, que exigem que ele encaixe a lata de uma determinada maneira para conseguir despejar o seu conteúdo no pilar, o ardor da mistura de suor e cimento nos olhos, a vertigem pela altura em que se encontra executando a atividade, o acúmulo de latas chegando e esperando para serem despejadas no pilar, dentre outras.

Além do esforço físico e psíquico necessários para a sua realização naquele contexto, o que mais a atividade observada exige do servente? Obediência? Submissão? Que efeitos produzem essas exigências? Que sentido(s) o sujeito confere a esse trabalho? Essas indagações nos convidam a, além do trabalho real (tudo aquilo que o servente faz além do prescrito pra viabilizar a execução da tarefa), considerar também o real da atividade (tudo aquilo que ele não fez e gostaria de ter feito, todos os conflitos internos com os quais teve que lidar ao longo do processo, todas as ações que chegou a considerar e decidiu não concretizar). ${ }^{5}$ É possível perceber que o trabalhador está imerso naquilo que Durrive e Schwartz (2008) denominam dramática do uso de si, conceito com o qual os autores, ao examinarem a complexidade inerente a todo ato de trabalho humano, visam devolver algo de grandeza àquilo que é considerado infinitamente pequeno ou negligenciável. Durrive e Schwartz nos ajudam a perceber que, executando a atividade observada, existe um sujeito fazendo uso de suas próprias capacidades, de seus próprios recursos e de suas próprias escolhas para dar conta de fazer algo.

\section{A condição de servente}

Ao lado das exigências, dificuldades e precariedades objetivas presentes no exercício de sua atividade, ao servente é também delegada a tarefa de lidar com a desvalorização de sua atividade e com um conjunto de discriminações a ele dirigidas, diretamente ligadas ao seu pertencimento à categoria profissional.

Ó, eu, pra ser honesto com você, em pouco tempo que eu trabalho na construção civil, deu pra se notar o seguinte: o trabalho de servente na área da construção civil, deu pra se notar o seguinte, ele é um pouco desvalorizado. Pra começar pelo próprio encarregado. Segundo, desvalorizado também, de uma certa maneira, até mesmo por alguns colegas de serviço. (...) "Ah, pera aí, você é um servente, sua obrigação é fazer essa limpeza, sua obrigação é deixar isso aqui limpo pra mim, entendeu? Se você quiser, bem, se você não quiser eu simplesmente vou chegar até o encarregado e vou pedir pra te trocar" (servente, André).

4 Ver Schwartz et al. (2007b, p. 95).

5 Ver Clot (2001). 
Em verdade, o servente sequer goza do status de profissional no setor, não chega a ocupar um cargo "oficial".

Quer dizê, arte é realmente a profissão da pessoa, quer dizê que a profissão é uma arte, entendeu? Seja o carpinteiro, o pedreiro, o marceneiro, o eletricista, o bombeiro, quer dizê, tudo é arte, entendeu? (Carpinteiro Carlos apud Sousa, 1983, p. 95).

Arte deve ser o seguinte, em qualquer profissão, né, ou seja, a única pessoa que num tem arte é servente, porque servente num tem arte não. Mas passando pra profissional, cada um tem sua arte, ou seja, mecânico, ou lanterneiro, ou jardineiro, ou pintor, ou carpinteiro, ou estucador, ou armador... todo profissional. Isso é arte (Carpinteiro João apud Sousa, 1983, p. 95).

[...] Eu acho que o servente, qualquer que seja ele, ele deveria correr atrás, mostrar mais interesse no serviço profissional pra ver se ele consegue uma classificação, porque aí tudo ajuda, em termos de salário, em termos de mais respeito, que eu acho que falta, com certeza, falta um pouquinho de respeito, o servente nunca ele é respeitado como profissional, e muitas vez exatamente por causa disso, porque eles não procura esforçá. Mas, a partir do momento que eles fazê o esforço da parte deles, eles vão conseguir um objetivo na vida, eles vão ter uma profissão. [...] Então eu acho que ocê tem que trabalhar com esse objetivo, de correr atrás de uma profissão, de um trem qualquer, senão vai ficando a vida inteira de servente (encarregado, Tião).

As duas primeiras citações - extraídas da pesquisa de Sousa (1983) realizada junto aos operários construtores de Brasília - deixam clara a noção de que, na construção civil, todos os operários detêm uma arte, uma profissão, com exceção exclusiva do servente. Já o relato do encarregado participante de nosso próprio estudo coloca em evidência que "um trem qualquer" seria melhor opção do que "ficar a vida inteira de servente". O esforço exigido é vinculado ao objetivo de deixar de ser servente para que, então, o sujeito passe a ser respeitado, entre outras coisas, como profissional. Tal perspectiva, compartilhada não apenas entre operários e encarregados, mas em todo o setor (demais níveis de gestão e até mesmo de ensino ${ }^{6}$ ), nos coloca uma questão inevitável: se não é profissão, o que é?

Muitas vezes... eu já trabalhei em uma obra que a gente era muito "isvalorizado". Assim, não são todos os pedreiros, muitas vez os pedreiro falava assim com a gente: "Ah, servente pra mim não é nada" (servente, Nil).

As análises apresentadas em nosso estudo sobre o trabalho do servente demonstram de forma inequívoca seu caráter de atividade profissional (Santos, 2010). Ainda que acolha trabalhadores sem qualificação prévia, a observação mais atenta da atividade revela que a formação profissional do servente ocorre na prática, no exercício do ofício, exigindo a aquisição de saberes especializados, bem como de competências ${ }^{7}$ determinantes para a correta, segura e eficaz realização de práticas específicas. Tais saberes investidos na atividade geralmente passam despercebidos pelos observadores e, amiúde, pelos próprios trabalhadores. A esse respeito, são ilustrativas as palavras presentes nas primeiras três frases do encarregado que, em meio ao diálogo com o grupo na entrevista, busca reformular sua colocação anterior:

Porque se ele como ajudante, ele sendo ajudante, ele é um profissional. Na atividade dele, ele é um profissional, né. Ele sabe fazer a massa, ele sabe atender o pedreiro, a pessoa que tá com ele, certinho, então eu acho que ele é um profissional também. Só que, às vezes, é igual eu tô acabando de te dizer, tem uns caras, é igual ele acabou de dizer aí, parece que não quer ter um objetivo na vida. Quer é ficar ali a vida inteira, né. Outras vezes, às vezes falta oportunidade, né. Mas, na maioria das vezes o cara parece que não quer ter um objetivo na vida. Eu acho que é isso (encarregado, Tião).

\footnotetext{
6 Fato constatado em conversas entre o pesquisador e docentes de uma das mais respeitáveis instituições de ensino superior em engenharia civil do Estado de Minas Gerais.

7 "Ser competente é tirar partido do meio, gerir as relações de antecipação e de encontro em função de valores, [...] antes de tudo, um 'agir' aqui e agora" (Schwartz et al., 2007b, p. 98 e 2007c, p. 207).
} 
A partir da quarta frase da citação, entretanto, o encarregado passa a atribuir quase exclusivamente ao querer do sujeito (ou à falta dele) a responsabilidade por suas condições de vida e trabalho. Ainda que se trate de uma perspectiva psicologizante e reducionista (incutida historicamente no imaginário social), tal olhar sobre a atitude resignada de muitos serventes, observada por ele e por vários operários (dentre eles, os próprios serventes), pode abrir caminho para a evidência de algo relevante sobre a categoria. Referimo-nos à nossa própria perspectiva de que, além de profissão, dado o contexto que a abraça, trata-se também de uma "condição", a condição de servente, em uma acepção consonante à postulada por Louis Le Guillant (2006) em seus estudos junto às empregadas domésticas. Mais do que o exercício de uma determinada atividade profissional, ser servente implica em um conjunto de vivências objetivas e subjetivas, de considerável impacto tanto na formação da identidade quanto na sociabilidade dos sujeitos marcados por essa condição. Tal aspecto de condição da categoria servente, que estigmatiza e desqualifica a situação e o sujeito que a ela se vinculam, é, em parte, apresentada nas seguintes falas de operários:

O cara não sabe nada, né. Aí, tipo assim, qualquer coisa que acontece, qualquer coisa, "ah, o cara é servente", fez qualquer coisa errada ali. Ele pode ser um pedreiro, que às vezes ele é pedreiro, mas, se fez qualquer coisa errada, os próprios colegas mesmo fala: "ah, o cara é servente, nem sabe trabalhar direito" (risos dos colegas ao fundo). O que mais acontece no meu modo de pensar é isso, né. "Não, o cara é servente", quer dizer, tá jogando o cara é pra baixo. Tipo assim, sabe, no meu modo de pensar é assim.

Pesquisador: O servente não sabe nada?

É, é o modo de dizer, né, o pessoal fala, né. Não é todo mundo que fala (pedreiro, Zezinho).

A marca (estigma) servente remete ao não saber nada e, conforme indicado na citação, é usada até mesmo direcionada aos oficiais. Já a ambiguidade dos sentimentos do sujeito para com a empresa e a profissão (que ocorre também na condição de doméstica) se expressa, por exemplo, em tudo aquilo que o faz negar o pertencimento à condição de servente, por um lado (atitude manifesta, entre outras coisas, no objetivo de ser classificado o mais rápido possível), e, por outro, a satisfação pelo ingresso concedido pela profissão ao universo do trabalho formal (outras portas não se abrem), a frágil proteção por ela oferecida diante do completo desamparo social (desemprego/indigência) e a identificação desse "degrau" como etapa fundamental para o acesso a melhorias nas condições de vida e trabalho.

[...] às vezes alguns não têm uma boa educação, não têm, assim, um grau de estudo, entendeu, e fica com receio de comentar, fica com receio de falar as coisas pelo seguinte, porque ele acha que, de uma certa maneira, que ele não vai ter a capacidade de entrar numa outra empresa, de trabalhar num outro setor de serviço (servente, André).

Assim, o servente é negado pelo contexto como sujeito (tarefas, colegas, chefia, organização, sociedade) e, enquanto deseja ele negar a sua condição, entende que, ainda sendo dura, é ela quem o acolhe e pode lhe oferecer condições mínimas de subsistência, seguridade (basicamente salário fixo, cesta básica, previdência social, FGTS e seguro desemprego), inserção social (através de alguma participação no processo produtivo), bem como algumas oportunidades de desenvolvimento profissional. Negação e afirmação, ressentimento e uma espécie de gratidão, atitudes e sentimentos que andam lado a lado caracterizando, portanto, um dos conflitos psíquicos que o servente deve gerir. Observemos as três falas de um mesmo servente:

Se fosse todo mundo, os servente, fosse tudo inguinorante, sabe o que ia acontecer? Ia falar assim:

"Ah, cê quer saber, eu acho que eu vou embora porque eu não tô sendo valorizado nem nada no serviço, então o que que eu vou fazer, eu vou embora, vou" (servente, Nil).

Vão supor, igual eu trabaiei em uma outra obra aí, eles muito disprezava de mim: "ah, ocê toda 
vida vai ser servente?", eu falei assim "ué, se eu gosto da minha profissão eu gosto, ué, eu não vou querer mudar de profissão". Muitas vez as pessoa jogava na minha cara que eu vou ser servente toda a vida, eu falo "não, eu vou ser, que é a minha profissão, que eu gosto, que eu amei". Mas, muitas vez, talvez a pessoa, igual, fala [...] rebaixar a gente, fala assim "ah, cê é bobo demais ser servente toda vida". Não é porque é servente toda vida, é porque a gente gosta da profissão da gente. Eu gosto do que eu faço (servente, Nil).

Servente é muito discriminado, porque não é profissão, é sofrimento (servente, Nil).

Alimentam ainda mais esses conflitos, ao lado do não reconhecimento e da desqualificação profissional, a vivência cotidiana da subserviência e impotência perante os constrangimentos impostos pelo e no trabalho. Tais situações são assimiladas como violência diante da qual os serventes parecem não encontrar meios eficazes de se defender, o que provoca impactos na autoestima dos sujeitos, conforme veremos a seguir.

\section{Humilhação e vergonha}

Seus olhos embotados de cimento e lágrima (Construção, Chico Buarque de Holanda).

Em seus estudos e escritos, o psicossociólogo Vincent de Gaulejac (2006) indica que pessoas submetidas a violências humilhantes (processos de estigmatização, coisificação, dependência e perda de dignidade) podem apresentar um sentimento de vergonha que se instala quando a identidade do indivíduo é alterada. Para ele, o que produz a humilhação é a negação da condição de humano, de semelhante, de cidadão ou de sujeito.

Diante de violências extremas, (o indivíduo) é invadido pela desumanização e pela confusão. As referências habituais que lhe permitem situar-se em relação aos outros e a si mesmo são fragilizadas ou destruídas. [...] O sujeito é dilacerado por tensões contraditórias entre a tentativa de salvaguardar sua unidade e a impossibilidade de consegui-lo sem rejeitar uma parte de si mesmo (Gaulejac, 2006, p. 103).

Aspectos da vivência de violências humilhantes e o seu impacto na autoestima dos sujeitos protagonistas da condição servente são observados nas falas que seguem:

A gente não tem vergonha de falar que a gente chora, mas quem fala que num chora, ele chora sim, porque, qualquer palavra que você falar com uma pessoa, você humilha a pessoa, igual muitas vez eu já fui humilhado (servente, Nil).

[...] talvez o pedreiro fala assim: "ah, cê vai ser burro toda a vida?", nunca deve falar isso com a pessoa porque ele pode magoar a pessoa, falar com a pessoa "ah, cê é obrigado a aprender" (servente, Nil).

Por que que hoje então está sendo aberto aí pela Prefeitura de Belo Horizonte, está sendo aberto ai por empresas, aqui mesmo você é prova disso, você traz vários cursos aí ó, pra implantar, entendeu, por que que muitos serventes não têm coragem de ir? Primeiro, às vezes é o próprio complexo de inferioridade. Porque palavras que machucam, palavras que revoltam a pessoa, a pessoa fica com aquilo na mente. [...] Então, quer dizer, o servente, às vezes ele aprende a ser um carpinteiro, a ser um pedreiro, porque ele não dá ouvido a isso... aquele que tem um pouco de personalidade, que às vezes aquele que tem um pouco, assim, ele cria na sua mente aquele complexo de inferioridade, entendeu, ele dá ouvido àquilo, ele fica traumatizado com aquilo e não faz. [...] Aí o que que acontece. O servente se auto se desvaloriza por si mesmo, tem aquele complexo de inferioridade, que ele nunca vai chegar, entendeu? "Ah, eu vou me esforçar pra que, eu vou fazer por quê? Eu vou fazer simplesmente pra mim ter o meu sustento ali mensal, só pra mim ajudar ali, ou pra mim pagar minha conta de água e luz", cê entendeu, "só pra mim ajudar 
dentro de casa." [...] E, infelizmente, é uma classe que, não desfazendo, porque hoje, no mercado, é onde que tá tendo mais requisição, entendeu, de mão de obra, mas, infelizmente, de uma certa maneira, ela é desvalorizada. Socialmente, socialmente. É a realidade (servente, André).

Ainda segundo Gaulejac, as violências humilhantes obrigam o sujeito ao enfrentamento de uma imagem negativa de si que o situa em uma contradição entre o que deveria ser para ser reconhecido socialmente e a identidade que lhe é atribuída. $\mathrm{O}$ autor postula o termo sofrimento social, dizendo que este nasce quando o sujeito é obrigado a ocupar um lugar social que o anula, desqualifica, coisifica ou desconsidera. É produzido, portanto, pelas contradições sociais que transpassam a identidade (repressão, exploração, exclusão), gerando um conflito que é internalizado adiante da impotência do sujeito de sair dessa posição, um conflito interno de origem externa. De um lado, a exclusão, o desamparo social, condições de vida e trabalho difíceis, penosas, que produzem, do outro, uma vulnerabilidade identitária, uma ferida narcísica, uma invalidação psíquica. Na perspectiva de Gaulejac, o sofrimento subjetivo provocado por esse conflito só pode ser atenuado por uma mudança objetiva de sua situação social. Tal sofrimento pode tanto paralisar como impulsionar o sujeito. Ele é criativo se leva o sujeito ao engajamento na busca de mudança da situação vivida e ao rompimento com a internalização do estigma. Por outro lado, é fonte de embotamento se inibe as potencialidades do sujeito, podendo levar à resignação e à passividade.

As contribuições do autor talvez nos ajudem a melhor refletir sobre aspectos subjacentes à aparente "falta de querer ter um objetivo na vida" apresentada por alguns serventes de acordo com o relato do encarregado anteriormente citado. Para toda dor/sofrimento buscase a "cura" (quando possível) ou o alívio, a anestesia (quando não mais se acredita em suas próprias forças para lutar e/ou na possibilidade daquela). Devido às restrições financeiras a que estão submetidos os serventes, observa-se que, com frequência, eles elegem um anestésico popular e genuinamente brasileiro para o enfrentamento do sofrimento cotidiano: a cachaça. A esse respeito, Fabiana Silva (2006) empreendeu um valoroso estudo ao buscar identificar e compreender as possíveis relações entre, de um lado, as situações concretas de trabalho e de vida de operários da construção civil e, do outro, os altos índices de quadros de alcoolismo entre os trabalhadores nesse setor.

\section{A negação da condição servente}

Quem proclama a fraqueza do outro revela sua própria estatura (Frei Cláudio van Balen).

É fácil notar nos canteiros de obra a marginalização dos serventes promovida pelo conjunto dos atores que povoam o campo, partindo dos engenheiros, passando pelos prestadores de serviço terceirizados, mestres de obra, encarregados e oficiais, chegando até os próprios serventes, através da internalização e/ou projeção do estigma. A discriminação excludente se faz presente, por exemplo, em comentários, "brincadeiras" e, principalmente, nas interações de trabalho estabelecidas entre os serventes e os atores apontados.

Dentro da construção civil, o que eu já notei é isso: a maioria de encarregados, a maioria de mestres de obras, entendeu, sai do próprio setor do trabalho. Não é errado, não. Ele fez por onde, por merecer. Cê tá me entendendo? Só que o seguinte, eles não têm, assim, muito diálogo, às vezes não sabem conversar, às vezes não sabem pedir, entendeu? (servente, André). 
Com apenas um pouco mais de atenção no olhar, é possível perceber também que, atrelada a essa reificação, exclusão e marginalização, subjaz a expressão de uma negação, a negação da condição de servente.

Num tô dizendo que o encarregado quer ser melhor que as pessoas, mas tem uns encarregados que gostam de ser melhor do que as pessoas [...]. Só isso (servente, Nil).

Porque tem muitos pedreiro também que cê trabalha com ele, mas ele não te dá chance. Ce tá trabalhano aí ele fala: "pode deixar isso aí, porque você vai fazer é cagada". Não são todos, né, mas tem alguns que falam. Porque tem muitas pessoas, que eles também já foi servente, né, mas tem muitas pessoas que, só porque eles pego um grau, eles pensa que já é mais, que já é mais alguma coisa que o outro. Não é (servente, Edson).

[...] tem muitos pedreiros que eu já trabalhei que gritam com o ajudante. Eu acho que ninguém gosta de ser chamado atenção e não precisa ser gritado também, né? Às vezes a pessoa tá daqui ali e tá gritando com a pessoa. Eu acho isso errado, também, acho chato (pedreiro, José de Fátima).

Mais uma vez é Gaulejac quem nos ajuda a melhor compreender o indissociável entrelace entre a subjetividade (individual) e a objetividade (social) presente nessa relação de negação do excluído, dos sujeitos que se situam à margem.

A figura do excluído revela a nossa própria vergonha. Se rejeitamos aquele que nos estende a mão, porque o consideramos um vagabundo, um enganador ou um delinquente potencial, é porque ele está nos remetendo à imagem daquilo que tememos nos tornar. Rejeita-se a relação, porque se recusa a identificação. Coloca-se o outro à distância, porque ele incomoda. Essa relação intersubjetiva, descrita aqui sumariamente, é profundamente social. Ela cristaliza as fraturas sociais que atravessam atualmente a nossa sociedade. É um efeito da "luta por lugares" entre os que batalham para conservá-los, os que procuram ter um lugar e os que não mais o têm. [...] Trata-se de uma questão social (Castel, 1995), que produz os efeitos psicológicos. Assim, torna-se essencial fazermos a distinção entre os determinismos socioeconômicos e suas consequências psicológicas. Ao querermos responder, no plano psicológico, a problemas de gênese social, corremos o risco de aprisionarmos os indivíduos na impotência e na culpabilidade. Mas, inversamente, ao esquecermos os efeitos psíquicos das situações sociais e econômicas, deixamos de compreender por que e como os indivíduos se mobilizam ou se desmobilizam para produzir a sociedade (Elias, 1939) (Gaulejac, 2001, p. 39).

Por mais que tenha em suas mãos a carteira assinada, que tenha conquistado o livramento do desemprego, o servente ainda assim não consegue se livrar do "seu" problema. $\mathrm{Na}$ "luta por lugares", ele permanece habitando um não lugar, talvez ainda mais incômodo do que aquele, pelo fato de o seu não pertencimento ao grupo lhe ser exposto amiúde e em um contexto mais circunscrito do que o da sociedade em geral. Diante do terror da anulação que assombra esse não lugar, todos dele se esquivam, sejam os que o habitam, os que por lá já passaram, seja os que sequer cogitam dele se aproximar, fazendo o possível, consciente e inconscientemente, para evitar o estabelecimento de qualquer identificação para com ele. Nesse sentido, a violência dirigida aos serventes através de comentários depreciativos, de atitudes desqualificadoras, do abuso do poder na forma da atribuição de determinadas tarefas extenuantes e/ou humilhantes, tudo isso pode expressar uma aversão e intolerância à condição de servente, isto é, à possibilidade de identificação de si mesmo como alguém desqualificado, sem valor, indigno de reconhecimento, invisível... enfim, à indiferença ao olhar do outro. Vejamos alguns depoimentos que ilustram a reificação e violência dirigidas ao servente:

Muitas vezes, assim, igual servente, muitas vezes pedrero chega, obriga o servente a lavar as ferramentas dele (...). "Ó, cê é obrigado a lavar minhas ferramenta, você está pra isso aqui". (...) Num é assim, não! Ele tem que chegar na humildade e falar: "ó, cê faz esse favor pra mim, lava 
essas ferramenta, e tudo". Aí o que que vai acontecer. Não, faço, com o maior prazer eu faço. Mas muita gente, igual eu mesmo já fui humilhado nisso aí (servente, Nil).

E quando às vezes acontece também o seguinte: "ó, nós tamo precisando que a empresa faz hora extra até as 20h, cê entendeu, ou até as 22h". Entre aspas, alguns encarregados chega e sabe conversar. Ele fala: "ó, Fulano, eu tô precisando que você fique até as $22 \mathrm{~h}$, há possibilidade?" Tudo bem. Agora, acontece também de, às vezes, o encarregado chegar até perto do servente e falar assim: "eu tô precisando que você fique até tantas horas". Se ele falar que não, de uma certa maneira começa uma perseguição com ele. Até ameaça verbal. Então além de ser um serviço pesado, certas horas, não são todas, entendeu, além de haver essa discriminação verbal, salarial, essa discriminação também, de uma certa maneira, do próprio colega de serviço (servente, André).

Em seus próprios estudos junto a trabalhadoras domésticas ("bonne à tout faire") Gaulejac identificou nos depoimentos daquelas dois elementos que, segundo pôde constatar, produzem a humilhação: a coisificação e a ausência de reciprocidade.

O processo de coisificação consiste em negar ao outro o fato de ser um homem entre os homens, em se recusar a considerá-lo como um ser humano, em tratá-lo como um objeto, como uma ferramenta a ser usada, que se pega quando é preciso e se larga quando não serve mais (Gaulejac, 2006, p. 74).

Tal aspecto é nítida e textualmente identificado junto aos serventes na seguinte fala:

O pior trabalho que existe na construção civil se joga na mão do servente. E quando ele às vezes não dá resultado, quando ele às vezes não chegou no nível que o encarregado queria, simplesmente ele é descartado (servente, André).

Na ausência de reciprocidade, prossegue o autor,

[...] a relação de poder é, portanto, "naturalizada" e torna-se intangível: um se considera como sujeito e o outro como um objeto, um selvagem, uma máquina ou um bárbaro. O primeiro tem a seu lado o direito, a cultura, a legitimidade e espera do segundo o dever, o silêncio, a resignação. A dominação consiste em considerar que o outro não é seu semelhante, que não tem as mesmas capacidades nem os mesmos direitos nem as mesmas atitudes e que estas diferenças justificam sua condição inferior. A não reciprocidade é a negação de que o outro possa chegar à condição de sujeito. É o contrário da alteridade, ou seja, o reconhecimento de que o outro pode ser "meu" semelhante, sejam quais forem as diferenças objetivas e subjetivas que nos separam. A reciprocidade não implica obrigatoriamente igualdade e, a fortiori, ausência de diferença. Implica o reconhecimento de uma virtualidade, a possibilidade de que o outro possa exercer o poder, atingir a cidadania, ser sujeito de direito... da mesma forma que todo mundo. Quando o outro é coisificado, tratado como objeto, e lhe é negada a possibilidade de ter uma vida social como qualquer cidadão, cria-se uma situação de violência e exclusão (Gaulejac, 2006, p. 74).

\section{Atribuição de tarefas e assédio psicossocial}

Essa forma de manifestação ofensiva de relações de poder verificada nos ambientes de trabalho que promove a corrosão da autoimagem do funcionário vem sendo contemporaneamente tipificada como Assédio Moral. O termo é legalmente definido no Brasil como 
[...] todo tipo de ação, gesto ou palavra que atinja, pela repetição, a autoestima e a segurança de um indivíduo, fazendo-o duvidar de si e de sua competência, implicando em dano ao ambiente de trabalho, à evolução da carreira profissional ou à estabilidade do vínculo empregatício do funcionário [...] (Lei 13.288, de 10/01/2002, art. 1o apud Vieira, 2008, p. 98),

por lei sancionada em âmbito municipal (São Paulo/SP), sendo o agente do delito passível de responsabilização penal. Não nos resta dúvida de que a categoria dos serventes é alvo frequente de assédio no trabalho; os relatos já citados ratificam essa clareza. Chama-nos especial atenção a questão das ameaças e "perseguições" dirigidas aos funcionários para os quais a gestão da obra deseja o desligamento, mas igualmente evitar as despesas trabalhistas. Dada a incipiência ou mesmo inexistência de métodos estabelecidos de seleção na contratação e de capacitação/treinamento dos operários, uma das razões que propiciam a elevada rotatividade (turn-over) na construção civil, essa é uma situação nada incomum.

Uma coisa que eu reparei, é, vão supor, existe ali aquele tubulão pra furar. Ali existe ali $40 \mathrm{~cm}$ de água. Aquela água ali já foi... durante três semanas tá ali. Por mais que a empresa te fornece o equipamento adequado, ele seleciona aquelas pessoas, porque tem algumas pessoas que têm coragem de falar assim: "eu não vou fazer isso". [...] eles preferem às vezes pegar aquela pessoa que tem menor conhecimento, que, digamos assim, não sabe se relacionar muito bem em palavras, e coloca ali e chega até às vezes até a ameaçar a pessoa. "Ó, se você não fizer isso aqui pra mim, pra mim você não serve; ou você faz, ou então você tá dispensado". Ou, ocorre muito também na área do servente, o que estava se colocando aqui, a discriminação verbal. Mau tratamento, mau tratamento. Ou você faz como eu quero ou então pra mim você não serve. (...) "Olha, o Fulano não serve, então eu vou colocar o Fulano só naquele setor de trabalho pior possível. Eu vou caçar um meio de arrumar uma advertência, vou caçar um meio de dar uma punição pro Fulano, porque ele pra mim ele não serve". Eu já notei isso. Eu já presenciei isso. Só que eu nunca quis falar pra não magoar a pessoa e também pra não criar maior atrito, cê entendeu, no setor de trabalho (servente, André).

Nós mesmos presenciamos e escutamos dos próprios engenheiros diferentes estratégias por eles utilizadas para provocar o pedido de demissão por parte do funcionário indesejado. Uma delas é atribuir-lhe a tarefa de ficar parado, sem atividade, sentado em um cômodo pequeno, quente, sob telha de amianto, durante todo o expediente. Essa atitude é carinhosamente denominada "colocar o peão na solitária". Mas a criatividade em um canteiro de obras vai muito além.

Ó, nesse período que eu tô na construtora, o pior que eu já achei foi lá no Ed. W. Lá, que o Fulano (nome do encarregado), eu não sei se o elevador quebrou, o que que aconteceu, entendeu [...] se o elevador quebrou, o que que foi [...], aí o (encarregado) me chamou, eu e o Beltrano (outro servente), ele pediu pra gente levá aquelas pedras de granito ${ }^{8}$ até lá em cima (18 andares). [...] Não foi dado equipamento de segurança pra gente poder usar adequado. Terceira coisa, tava uma cobrança danada por causa dessas pedras, entendeu, então eu, particularmente, eu não gostei, eu não agradei [...]. Porque levava um risco grande da pedra quebrar com você, machucar quem tava juntamente com você e, além desse risco também, é, de uma certa maneira, você até deslocar a sua coluna. Aí, nessa hora, como se diz, o encarregado, é a realidade, "eu não mandei fazer isso não". Porque ele sabe que ele vai ser cobrado, ele sabe que a empresa vai ter que preencher uma $\mathrm{CAT}^{9}$ de acidente de trabalho, entendeu. Aí ele sabe que o engenheiro vai vim em cima dele, entendeu, aí o encarregado: "não, eu não mandei fazer isso não". Quer dizer, há duas controvérsia, quando ele quer que ocê faz o serviço, entendeu, cê faz, tudo bem, mas quando acontece algum acidente, acontece alguma coisa, "de jeito nenhum, pedi não". Então é uma coisa que acontece muito que eu já notei. Na minha opinião, dos piores foi esse. Eu fiz, não recusei o

8 As pedras mencionadas (granito moonlight) apresentavam dimensão de $85 \times 95 \times 2$ centímetros e pesavam cerca de 70 quilos cada uma.

9 Comunicação de Acidente do Trabalho, CAT. 
trabalho, que é a minha obrigação, no meu posto de trabalho, entendeu. Porém eu não corri, não me estressei, como ele desceu várias vezes a escada, "tá pesado aí, André?" Nem resposta eu dei (servente, André).

Se por um lado, conforme apontam Vieira (2008) e Lima (apud Vieira, 2008), a emergência do termo Assédio Moral se fez importante por denunciar e colocar em evidência de forma conceitual as implicações nocivas para a saúde física e mental do trabalhador promovidas em meio a relações de trabalho degradantes, por outro se nota que prevalecem em torno do tema análises superficiais e psicologizantes. Em geral, essas análises apontam o assédio como o produto de "um choque entre personalidades, no qual o assediador é quase sempre qualificado como perverso e o assediado como uma vítima indefesa" (Lima apud Vieira, 2008). Trata-se de "uma perspectiva reducionista e enviesada, que desconsidera os contextos de trabalho e suas exigências como fatores essenciais para a compreensão do problema" (Lima apud Vieira, 2008). O foco de uma análise pertinente deve se assentar "na articulação sujeito/organização do trabalho, e não nas características pessoais do 'assediador' ou do 'assediado', vistas de forma isolada" (Lima apud Vieira, 2008, p. 16). Em outras palavras, o trabalho e os contextos sóciohistórico, econômico e político que o atravessam não podem ser considerados como meras contingências da manifestação do assédio.

Sendo os conflitos, portanto, engendrados no e pelo trabalho, em nosso próprio estudo sobre os serventes afirmamos filiação à noção de Assédio Psicossocial, tal qual discutida por Vieira (2008). Dessa forma, entendemos que os oficiais, os encarregados, os mestres de obras, bem como os engenheiros, ao lado dos serventes, são também trabalhadores, cidadãos, sujeitos sociais e, dentro das características peculiares que distinguem suas respectivas categorias, agem sustentados (e pressionados) por um contexto sócio-histórico que os atravessa. No último relato citado, por exemplo, uma análise ergonômica da atividade do encarregado, pivô do conflito em questão (a atribuição ao servente da tarefa de carregar pedras grandes e pesadas subindo e descendo 18 andares, e o uso da autoridade e poder para fazê-lo), certamente indicaria um contexto de significativa pressão vivenciado pelo "assediador" ["que tava uma cobrança danada por causa dessas pedras"]. Mediante uma visão assumidamente superficial, arriscaríamo-nos a dizer que, na "luta por lugares" (Gaulejac, 2001), assim agindo ele busca defender, com as armas que entende dispor, o lugar conquistado na hierarquia de trabalho (e as melhorias nas condições de vida e na autoimagem por este proporcionado). Se não são colocados em análise a organização do trabalho, os valores da organização que orientam as condutas dos gestores e, ampliando a visão, os valores e ditames socioeconômicos que caracterizam o contexto maior em que essa organização busca se inserir de forma competitiva, as tentativas de entendimento dos conflitos no trabalho não têm meios de escapar ao viés psicologizante. Será sempre mais simples e cômodo - embora ineficaz - responsabilizar (e punir) os indivíduos isoladamente em lugar de se investir nas transformações em que todos os envolvidos possam ter oportunidade de opinar e participar. Fechando essa reflexão, por sua importância fundamental, convidamos a colaboração de Yves Schwartz:

Se não se faz um esforço de ir ver de perto como cada um não apenas "se submete" - entre aspas -, mas vive e tenta recriar sua situação de trabalho, se não se faz esse esforço, então interpreta-se, julga-se e diagnostica-se no lugar das próprias pessoas e isso não pode produzir resultados positivos (Schwartz et al., 2007a, p. 26). 


\section{Enfraquecimento do coletivo e estratégias de resistência - a questão política}

Conforme enfatizado sob diferentes ângulos, o discurso que prevalece acerca dos serventes é desqualificador e discriminatório. Nossa investigação demonstrou que tal discurso contradiz o real, isto é, a complexidade presente na atividade e o seu importante papel no processo produtivo. Se, por um lado, mostra-se necessário compreender o contexto no qual ele é forjado e os atores direta e indiretamente envolvidos, por outro não se pode prescindir de avaliar seus efeitos, não apenas no nível individual, mas também no social e político. Colocando a questão de outra forma, a que $(\mathrm{m})$ serve a desqualificação do trabalho do servente?

Porque se todo mundo contra um só, hm... jamais cê vai ser alguém na vida. Porque a gente só é alguma coisa se todo mundo ajuntar. É igual uma formiguinha carregando um tanto das coisas. É só assim que a gente sobe na vida. Porque ninguém sobe na vida sozinho. Pra alguém ser alguma coisa na vida aqui tem que ter uma outra pessoa que já tá no nível mais alto, que mostra interesse, e a gente também mostrar interesse, né, pra ajudar a gente. Qualquer pessoa no mundo. A vida é essa (servente, Edson).

Pode-se dizer que a profissão de servente é "democrática", isto é, acolhe a (quase) todos. ${ }^{10}$ Nesse sentido, ela exerce importante função social, sendo a atividade veículo de inserção do sujeito marginalizado ${ }^{11}$ no grupo social economicamente ativo e (com maior efeito) produtivo. Não obstante, uma vez cruzada a fronteira (exclusão total / inclusão relativa), importa à manutenção do status quo que esses sujeitos recém-chegados à base produtiva da achatada pirâmide socioeconômica interrompam aí (ou bem próximo daí) a sua mobilidade social. Acima deles há toda uma intricada estratificação, em cuja ascensão mostra-se tarefa hercúlea e, para alguns níveis, lotérica. Assim, conforme apontado no relato, é necessário ao servente o estabelecimento de algum tipo de coalizão para viabilizar a melhoria das condições de vida e trabalho. Tal coalizão pode se dar pela via da organização coletiva ["a gente só é alguma coisa se todo mundo ajuntar"] (lógica da luta pelo direito - êxito compartilhado, aparentemente improvável e a longo prazo) ou pela via hierárquica ["Pra alguém ser alguma coisa na vida aqui tem que ter uma outra pessoa que já tá no nível mais alto, [...] né, pra ajudar a gente"] (lógica da ajuda, do favorecimento - êxito individual, mais tangível e a médio prazo).

Identificamos aqui uma função importante da desvalorização da categoria dos operários, de uma maneira geral ("peões") e, de forma mais específica e incisiva, dos serventes/ajudantes ("oreias-secas"), que correspondem ao maior contingente. Uma vez estabelecida a naturalização dessa desvalorização e, além dela, sua internalização por parte dos serventes, promove-se o esvaziamento da atividade como profissão e, através disso, o aniquilamento da categoria como organização coletiva. Tal situação apresenta um desconcertante (e envolvente) desafio às Clínicas do Trabalho, em especial à Clínica da Atividade de Yves Clot. Tal abordagem aposta na defesa e orgulho da profissão através da qualidade do trabalho, da beleza do gesto bem feito, da coisa bem pensada, da coisa alcançada, como a melhor forma de resistência contra as condições de trabalho inaceitáveis, bem como a melhor garantia da saúde do trabalhador. Como disciplina clínica, ela visa restituir o poder do sujeito sobre a situação, utilizando o coletivo como recurso para o desenvolvimento da subjetividade individual. ${ }^{12}$ Mas como agir quando se consegue esvaziar a profissão como tal, promovendo não o orgulho, mas a vergonha quanto ao pertencimento à categoria? Segundo Paugam (2008), esse tipo de cenário é favorável ao estabelecimento de uma situação de

10 Importa destacar que falamos em profissão a partir do conceito de métier trabalhado pela Ergologia e o desenvolvimento de competências na experiência cotidiana de trabalho que constitui o métier (Schwartz \& Durrive, 2009).

11 Ver Santos (2010).

12 Salientamos que o "coletivo" remete aqui à profissão como história comum, herança coletiva do pensar e do saber sobre o trabalho, e não à organização de classe, ainda que essa possa se valer daquele. 
isolamento, na qual o sujeito procura dissimular a inferioridade de seu status no meio em que vive e manter relações distantes com todos os que se encontram na mesma situação. Falando dos pobres de maneira geral, o autor afirma que "a humilhação os impede de aprofundar qualquer sentimento de pertinência a uma classe social" (Paugam, 2008, p. 66), promovendo o enfraquecimento e até a ruptura dos vínculos sociais, ou seja, o fechamento do indivíduo sobre si mesmo.

Percebemos assim que a desvalorização da profissão do servente parece atender, não menos que a outros motivos, a uma função de controle social (Barros, 2009), de manutenção da subalternidade e subserviência, isto é, a manutenção do status quo nas relações de poder estabelecidas entre uma classe socioeconômica numericamente minoritária sobre uma massa produtiva. A reprodução dessa estratificação é descrita de forma simples e clara pelo carpinteiro construtor de Brasília:

\begin{abstract}
Porque o engenheiro estudou, né, gastou muito dinheiro pra "estudá". E o "trabaiadô", o que gastou? Num gastou nada. A sina do "trabaiadô" é "trabaiadô" toda a vida... O engenheiro, porque tem possibilidade, é filho "dum doutô", estudou muito, gastou muito dinheiro, uma formatura não é brinquedo. Quem é "trabaiadô"? Que formatura o "trabaiadô" tem? Num tem nada. A formatura do "trabaiadô" é como a classificação dele. A formatura do carpinteiro é o martelo e o serrote, a formatura do "pedrero" é a colher e o prumo, a formatura do servente é a pá e o carrinho (carpinteiro João apud Sousa, 1983, p. 123).
\end{abstract}

A resignação e a subserviência dos trabalhadores como iniciativas de defesa encontram, entretanto, seus próprios limites diante das situações cotidianas de conflito promovidas pela vivência da exploração, humilhação e sentimento de impotência. Nesse sentido, ainda que de forma individual, frágil e isolada, observam-se no canteiro atitudes de autodefesa e resistência perante as situações vividas. Alguns optam pelo enfrentamento direto, feito às claras, determinando certos limites dos quais não abrem mão para a execução das atividades delegadas, como a reação do servente convocado a carregar as pedras de granito por 18 andares, conforme relatamos.

Esse tipo de atitude, contudo, expõe o trabalhador a uma série de riscos referentes às retaliações mencionadas, dirigidas a todos aqueles que, de alguma forma, questionam abertamente a autoridade (e a arbitrariedade) dos seus superiores hierárquicos. Assim, os trabalhadores desenvolvem outras modalidades de resistência, em um embate menos direto. Vejamos o exemplo do bem mandado:

[...] uma pessoa bem mandada, se ocê falar com ele: "eu quero que ocê busca lá em baixo pra mim dez litros d'água", ele desce tranquilo, vem com os dez litro d'água e põe pra você, entendeu? Esse é o bem mandado, no meu ponto de vista, pelo que eu vi aqui na construção civil, entendeu? Então, quer dizer, ele só faz aquilo que o pedreiro pede. [...] Quer dizer, a diferença entre o bem mandado praquele que procura ser ativo naquilo que vai fazer, entendeu, eficaz, é essa aí no meu ponto de vista (servente, André).

Então, tem cara, igual ontem eu tava trabalhando com o irmão dele, então tudo cê tem que ficar pedindo o cara. "Faz isso, busca aquela pedra ali pra mim, pega essa peça". Então eu acho que isso atrasa a gente, atrapalha a gente, cê entendeu? (pedreiro, Helbert).

Uma vez que a boa interação e eficiência produtiva entre oficiais e serventes dependem significativamente de sua atitude de antecipação, uma forma de resistência que apresenta impacto considerável é a obediência estrita ao prescrito. ${ }^{13}$ Se ao servente é delegada a tarefa de acatar e cumprir ordens, é exatamente isso que alguns fazem, de forma literal, prejudicando assim a agilidade na cadência do processo produtivo. Não sendo devidamente reconhecidos

13 Com efeito, tendo em vista a irredutível defasagem entre o prescrito e o real (Duraffourg et al., 2007, pp. 68-69), que sempre convoca o trabalhador a fazer uso de si e gerir essa distância (Schwartz et al., 2007b, p. 192), a obediência estrita ao prescrito é uma poderosa e conhecida estratégia de resistência dos trabalhadores. 
nem respeitados como profissionais e como sujeitos, assim como desiludidos com a possibilidade de ascensão profissional/social, os trabalhadores respondem com certa ironia, acatando prontamente e realizando até mesmo de forma bem feita as tarefas atribuídas, mas sem demonstrar interesse ou envolvimento com as metas estipuladas pela organização. Parecem defender sua integridade pessoal recusando "vestir a camisa da empresa", tratando com indiferença aqueles que assim também os tratam.

Porque, é aquela história, eu vou ficar dando murro em ponta de faca se eu sou um bom funcionário, se eu desponto naquilo que me pede pra fazer tudo, cê acha que eu como servente eu vou ficar dando murro em ponta de faca, vamos dizer assim, ditado popular, sendo que eu não tô sendo reconhecido, sendo que eu não tô tendo nenhuma benfeitoria em prol da minha pessoa? Claro que não (servente, André).

Um pouco mais explícito em sua resistência do que o bem mandado é o servente "nó -cego" ou "morcego":

O servente nó-cego é esse, por exemplo, cê tá fazendo, vão supor que você tá trabalhando numa alvenaria. Falta material, aí [...] ele põe massa e não põe tijolo, quando tem tijolo ele traz uma massa dura. Aí cê tem que ficar falando com ele: "ou, traz uma massa pra colocar nessa massa aqui" (pedreiro, José de Fátima).

[...] tem uns que sai, deixa o pedreiro sozinho, aí, na hora que o pedreiro vai precisá dele ele não tá perto do pedreiro. Aí o que que acontece? O pedreiro fica com raiva, aí chama o encarregado e fala: "ó, esse servente aqui não serve pra mim, ele tinha que ficar perto de mim, pra o que eu precisar ele tá me servindo, mas ele não tá". (...) Suponhamo, igual, no caso, se ele tiver em cima do andaime, entendeu. Ele não pode descer ali embaixo pra fazer outra coisa. Aí o servente vai e some, vai e some pra lá e esquece do pedreiro. Então, por isso, nesse negócio de morcego é por causa disso. O servente ele não faz nada, aí ele esconde lá, aí pronto. Eles arruma essa encrenca aí, o pedreiro fica com raiva por causa disso (servente, Nil).

É esse que é o nó-cego, às vez ele chegava, talvez vai pra um lugar, ai ele fica escondido lá, talvez ele até dorme, ele caça um lugar lá e fala: "ah, o caixote (de massa) tá cheio mesmo", então ele vai dormir (servente, Nil).

Via de regra, o atrito produzido nessa relação de conflito estabelecida entre trabalhadores e empresa caracteriza-se como mais um dos aspectos mantenedores da alta rotatividade no setor. O servente trabalha, resiste/reage, é demitido, lança mão do Fundo de Garantia (FGTS) e do Seguro Desemprego, entra em uma nova empresa, trabalha, resiste/reage, é demitido, e assim perpetua-se o ciclo.

O cara não pode desistir de nada, né. Se uma porta fecha, tem dez, vinte pra abrir pro outro. O cara tem sempre que lutar, né. Num pode deixar... [...] Cê tem que lutar, na vida tem que lutar (servente, Edson).

Outras formas de reação por nós observadas encontram meios mais agressivos para se externar. Algumas se dão através de atos anônimos, como o de passar fezes pela parede do banheiro, danificar equipamentos e/ou serviços já realizados, promover situações de grave risco (como lançar um bloco de tijolo do alto do poço do elevador), furtar objetos de uso coletivo (torneiras, chuveiros) ou privado (ferramentas, equipamentos e objetos de colegas). Outras vezes o anonimato não pode ser mantido. Isso se dá quando a reação vem à tona de forma explosiva, por meio de agressões físicas (geralmente entre colegas) e/ou de ameaças verbais (por vezes dirigidas aos encarregados e mestres). ${ }^{14}$ Finalmente, o álcool, a religião e a identificação

14 A agressividade reativa, tanto física quanto verbal, certamente não se apresenta apenas no ambiente do trabalho. Alguns relatos nos indicam que ela se manifesta, provavelmente com frequência ainda maior, também no ambiente doméstico, projetada nos familiares (principalmente esposa e filhos). 
(moral) com o próprio trabalho se apresentam como formas alternativas de lidar com o sentimento de impotência e exclusão.

[...] engraçado: a pessoa ficando meio de fogo, tudo pra ele tá bom. Então, às vez, a pessoa tá meio invocado, meio pensativo, então ele parava de pensar um bocado nas coisas, parece que as coisa ficava mais fácil. A pessoa, tando bêbada, não importava não (servente João, apud Silva, 2006, p. 131)

[...] eles (os superiores hierárquicos) é os mais forte, eles sabem o que que é melhor pra eles, pra gente, né. Mas Deus tá no controle (servente, Ivan).

Se ocê trabalha muito, né, eles fala que a gente é puxa-saco. Mas não é porque é puxa-saco. Se ocê saiu de casa pra ir trabalhar, cê tem que trabalhar, ué. Se cê quer ficar à toa, cê tem que ficar em casa, não é não? Tô certo ou tô errado? Puxa-saco é aquele que chega, chega e entrega a pessoa. Fulano de tal tá parado ali. Náo é, não? Tô certo ou tô errado? É aquele é que é o puxasaco. Se ocê tá trabalhando, ocê não é puxa-saco, não, cê tá trabalhando, que é sua obrigação, uai, fazendo sua obrigação. É o que acontece comigo. Sempre uns fica chamando eu de puxasaco. Mas não sou puxa-saco, não, uai. Saí de casa pra ir trabalhar, vou trabalhar. Né não? (pedreiro, Pedro).

Nota-se, portanto, que a abertura e o acolhimento quase irrestritos oferecidos pela profissão de servente ao cidadão brasileiro que não apresenta (ou quase não apresenta) grau de escolaridade, experiência e/ou qualificação específica desempenham importante papel de inclusão produtiva desses sujeitos no tecido social. Esse ingresso, entretanto, parece atender mais às necessidades e interesses econômicos do que a um projeto civilizatório de universalização da inclusão social através da oferta de trabalho digno, seguro, com oportunidades de desenvolvimento da qualificação e justa distribuição das riquezas auferidas. Trata-se, logo vemos, não de um "passaporte" para a cidadania democrática, mas de um "passe", uma permissão à participação parcial e conveniente, caracterizada pela delimitação restrita da mobilidade social da classe trabalhadora. Esse "acolhimento" carrega consigo, portanto, um profundo cinismo, caracterizando uma comunicação de duplo vínculo ${ }^{15}$. Sob o enquadramento desse contexto sociopolítico, a desqualificação da profissão de servente mostrase como eficiente mecanismo ideológico de manutenção do status quo e evitação de conflitos e confrontos sociais.

Na legitimação da exclusão, é necessário encontrar uma vítima expiatória sobre quem descarregar o pecado de marginalização, ou quase genocídio, de milhões. Essa vítima é o próprio excluído. O culpado não é um sistema, baseado em relações excludentes, que faz milhões de pobres. Não existe, dentro da ideologia liberal, espaço para o social. Por isso o ser humano é definido como um indivíduo, isto é, alguém que é um, mas não tem nada a ver com os outros. O ser humano, pensado sempre fora da relação, é o único responsável pelo seu êxito ou seu fracasso. Legitima-se quem vence, degrada-se o vencido, o excluído (Guareschi, 2008, p. 154).

Impotentes para realizar isoladamente o efetivo enfrentamento da realidade posta, parecem restar àqueles marcados pela condição servente limitadas e ineficazes manifestações de resistência que, em geral, acabam por reforçar a representação depreciativa que deles é feita por parte de outros profissionais, principalmente aqueles de nível gerencial, representação explicitada em expressões como: "veja como são animalescos esses peões, espalham fezes nas paredes", "não têm cérebro, não pensam, apenas conseguem executar estritamente o que lhes é ordenado", "são preguiçosos, não gostam de trabalhar, têm que ser vigiados a todo momento, pois basta uma rápida distração e já estão morcegando".

15 Duplo vínculo: termo cunhado pelo antropólogo inglês naturalizado norte-americano Gregory Bateson. Trata-se de uma situação que se estabelece quando uma pessoa se vê diante de mensagens simultâneas de aceitação e rejeição. $\mathrm{O}$ fato de tais mensagens serem simultâneas e contraditórias faz com que quem as recebe fique confuso (Mariotti, 1995). 


\section{Considerações finais}

Iniciamos nosso trabalho indicando o lugar em que ele se assenta: no incômodo gerado pela percepção do "não lugar" atribuído ao servente da construção civil - seja como profissional, seja como sujeito - e os efeitos (objetivos e subjetivos) dessa condição. Ao nos lançarmos à investigação, percebemos que a desqualificação dos serventes traduz um erro, tão antigo quanto contemporâneo. Paralelamente aos dados e observações do setor relativos às (penosas) condições de trabalho e de (in)segurança a que são submetidos esses trabalhadores, é a contradição presente na análise que fazem os oficiais sobre a atividade do servente o que melhor evidencia o equívoco e alimenta o incômodo. Encontramos aí um marcante paradoxo entre o discurso dos pedreiros quando falam do servente no senso comum ("aquele que não sabe fazer nada") e o discurso desses mesmos pedreiros quando falam do servente tendo no foco de análise o trabalho real ("sem o servente o pedreiro não faz nada, isto é, faz, mas muito menos"). A reflexão dos serventes sobre o próprio trabalho também evidenciou alguns dos múltiplos saberes e competências investidos em suas atividades, situação antagônica ao fato de, amiúde, eles mesmos introjetarem e reproduzirem a representação desqualificadora do senso comum sobre o ofício que exercem. Tais observações nos fazem perceber que a noção equivocada acerca da atividade do servente na construção civil mostra-se nociva tanto aos sujeitos submetidos a essa condição quanto à própria organização do trabalho, que subestima o impacto da participação daqueles no processo produtivo.

O estudo apontou que o desenvolvimento tecnológico em muito favoreceu o avanço do setor, inclusive no que se refere às condições de trabalho. Entretanto, percebe-se que essa evolução não foi acompanhada pelo desejável desenvolvimento das relações de gestão, da organização do trabalho e pelo investimento no desenvolvimento dos próprios sujeitos que habitam esse campo produtivo e "colaboram" com sua força de trabalho. Destacamos aqui uma das constatações conclusivas, feita à luz do estudo realizado: em plena entrada do século XXI, parece-nos contradição ética e moralmente insustentável a coexistência dos mais sofisticados mecanismos de produção de conhecimento e de riquezas e a sujeição de seres humanos a relações/situações de vida e trabalho humilhantes e/ou degradantes, como verificado na construção civil, em especial, junto à categoria dos serventes. Em uma época na qual sustentabilidade e responsabilidade socioambiental são palavras de ordem, proclamadas aos quatro ventos pelos discursos desenvolvimentistas, ousamos denunciar como hipócrita e ideológica toda e qualquer iniciativa que, sob esse selo, se proponha a mitigar ou reparar os danos provocados pela exploração e a exclusão sem avaliar, crítica e honestamente, como seus promotores contribuem para a gênese do problema em questão. Melhoria das condições de vida de trabalhadores sem a melhoria das suas condições de trabalho? Melhoria das condições de trabalho sem a aproximação in loco da realização desse trabalho e sem o envolvimento e respeito ao ponto de vista dos trabalhadores? Sob inspiração e orientação de ergólogos e ergonomistas, isso não nos parece iniciativa eficaz.

Nossa segunda constatação: ainda que sob a lógica reinante e linear da produtividade máxima e da idolatria ao lucro, a negligência de investimentos focados no desenvolvimento humano, nos contextos de trabalho, mostra-se contraproducente. A Ergologia e a Ergonomia demonstram que, mesmo dispondo da mais avançada tecnologia, a atividade industriosa não pode, em tempo algum, prescindir da ação (gestão) humana, visto ser o meio "sempre infiel" e que as defasagens entre o prescrito e o real demandam gerenciamento. Reconhecido como indispensável à produção, o homem, por sua vez, não deve ser tratado como máquina, "recurso" destituído de sua humanidade, sob o risco de se pôr a perder a referida implicação (quando não a saúde) dos trabalhadores e, como consequência, a produtividade, a qualidade e, finalmente, o lucro almejado. Nesse contexto, observa-se a ineficácia das modernas iniciativas "motivacionais" dirigidas aos trabalhadores, que, se por um lado compreenderam a impossibilidade de fragmentação e mecanização plena do agir humano, via de regra, são 
elaboradas sem a devida consideração das situações reais de trabalho, bem como do ponto de vista de seus protagonistas.

No contexto específico do trabalho dos serventes na construção civil, notamos ser amplamente subestimado o papel dos saberes e competências desses atores no processo produtivo, principalmente aqueles relativos ao trabalho de cooperação e assistência junto aos oficiais. Alimentada por essa subvalorização, é flagrante a negligência de investimentos nas áreas de formação técnica e de gestão/organização do trabalho das equipes. Entendemos que o campo mostra-se fértil para o desenvolvimento de outros estudos que venham demonstrar de forma mais precisa quanto "a incompetência (das organizações) em termos humanos" (Lima, 1996) prejudica a eficiência e a produtividade no setor.

Nossa terceira constatação: estando o mercado sujeito à lógica imperativa do lucro, a organização da sociabilidade humana não pode ser por ele livremente regulada. Tal ponderação não caracteriza um mero discurso ideológico, como podem alertar as recentes crises econômicas mundiais. Ainda dentro do sistema hegemônico, é imprescindível que o Estado assuma seu papel regulador, fiscalizador, e implemente políticas públicas que permitam um mínimo de sustentabilidade a esse sistema que, por natureza, é voraz e autofágico. ${ }^{16}$ Sem a correta ação e regulação do Estado na indústria da construção civil, por exemplo, organizações que, agindo de forma isolada, se disponham a verdadeiramente investir em segurança, em melhorias das condições de trabalho, na qualificação profissional e em uma distribuição mais justa das riquezas produzidas, em curto prazo, se mostrarão pouco competitivas, nada atraentes ao olhar dos investidores, sendo, assim, alijadas do mercado.

Finalmente, nossa consideração crítica sobre os valores e atitudes que caracterizam o modelo socioeconômico globalmente hegemônico na contemporaneidade. Apresentamo-la à luz de um questionamento em particular, cuja apreciação consideramos pertinente: na dialética relação entre o "Ser" (caracterizado pela autonomia, liberdade e responsabilidade ética dos sujeitos) e o "Poder" (caracterizado pelo acúmulo de capital e consequente influência e controle social), quem se mostra senhor e quem se mostra escravo na contemporaneidade? Ainda nesse sentido, levando-se em consideração que todos nos encontramos envolvidos - capital, patrões, empregados, desempregados -, mesmo que sob condições materiais de existência substancialmente distintas, quem aliena e quem é alienado? Sócrates, o filósofo, defendeu famosa tese segundo a qual "ninguém faz o mal voluntariamente, mas por ignorância, pois a sabedoria e a virtude são inseparáveis". O poeta canta que "a felicidade mora ao lado (na relação) $e$ quem não é tolo pode ver". ${ }^{17}$ Como realizar a passagem da velha (e atual) ordem social às novas construções do trabalho no mundo permanece desafiante enigma. Os concretos limites socioambientais impostos, em âmbito global, pelo modelo vigente, são quem nos interpelam, conferindo clima de certa urgência ao contexto político das iniciativas, dos embates e dos debates ("Decifra-me ou devoro-te!"). Uma vez que a resposta ao enigma já foi ensaiada ("o Homem"), talvez, ainda que pareçam por demais imprecisos ou abstratos, os investimentos no desenvolvimento da consciência humana (presença atenta; sabedoria; virtude; transcendência do ego) venham se mostrar vias concretas que sirvam de pavimento à referida passagem.

16 Para uma didática síntese a respeito da insustentabilidade do sistema linear de extração, produção, consumo, acumulação e despejo, vide o vídeo The story of stuff (A história das coisas), de Annie Leonard, um curto, polêmico e envolvente documentário sobre o ciclo de vida dos bens de consumo: http://www.youtube.com/ watch?v=3c88_ZOFF4k 


\section{Referências}

Almeida, J. L. O. (2010). Perspectivas para a construção. Recuperado em 10 de maio de 2010 de http://www.sindusconmg.org.br/site/artigos.php?id=1173

Barros, V. A. (2009). O Trabalho na contemporaneidade: Delimitações em um mundo de exclusão. In F. Kyrillos Neto, R. O. Silva \& R. T. Oliveira (Orgs.), Subjetividade(s) e sociedade: contribuições da psicologia (pp. 142160). Belo Horizonte: CRP.

Bressan, F. (2000). O método do estudo de caso. Administração On Line, 1 (1). Recuperado em 23 de outubro de 2007 de http://www.fecap.br/adm_online/art11/flavio.htm

Carreteiro, T. C. O. \& Barros, V. A. (2010). Clínicas do trabalho: contribuições da psicossociologia no Brasil. In P. F. Bendassolli \& L. A. P. Soboll (Orgs.). Clínicas do trabalho: perspectivas francesa e brasileira. São Paulo: Atlas.

Clot, Y. (2001). Clínica do trabalho, clínica do real (K. Santorum \& S. L. Barker, trad.). Le journal des psychologues, 185.

Coutinho, C. P. \& Chaves, J. H. (2001). Investigação em tecnologia educativa na Universidade do Minho: uma abordagem temática e metodológica às dissertações de mestrado concluídas nos cursos de mestrado em educação. In A. Estela \& J. Ferreira (Orgs.), Tecnologias em educação: estudos e investigações (pp. 289. 302). Actas do Colóquio da AFIRSE/AIPELF, 10. Lisboa: Universidade de Lisboa.

Duraffourg, J., Durrive, L. \& Duc, M. (2007). O trabalho e o ponto de vista da atividade. In Y. Schwartz \& L. Durrive (Orgs.), Trabalho $\mathcal{E}$ ergologia: conversas sobre a atividade humana (pp. 47-82). Niterói: UFF.

Durrive, L. \& Schwartz, Y. (2008). Revisões temáticas: glossário da ergologia. Laboreal, 4 (1), 23-28.

Gaulejac, V. (2001). Psicossociologia e sociologia clínica. In J. N. G. Araújo \& T. C. Carreteiro (Orgs.), Cenários sociais e abordagem clínica. São Paulo: Escuta.

Gaulejac, V. (2006). As origens da vergonha. São Paulo: Via Lettera.

Guareschi, P. A. (2008). Pressupostos psicossociais da exclusão: competitividade e culpabilização. In B. B. Sawaia (Org.), As artimanhas da exclusão: análise psicossocial e ética da desigualdade social (pp.141-156) (8oed). Petrópolis: Vozes.

Le Guillant, L. (2006). Incidências psicopatológicas da condição de "empregada doméstica”. In M. E. A. Lima (Org.), Escritos de Louis Le Guillant: da ergoterapia à psicopatologia do trabalho. Petrópolis: Vozes.

Lima, F. P. A. (1996). Conflitos sócio-cognitivos e ética na atividade de controle de qualidade. In F. Lima \& J. Normand (Orgs.), Qualidade da produção, produção dos homens (pp. 154-183). Belo Horizonte: DEP.

Lhuilier, D. \& Clot, Y. (2010). Agir en clinique du travail. Paris: Érès.

Mariotti, H. (1995). Gregory Bateson: um cérebro privilegiado. Revista Thot, 60, 23-27.

Paugam, S. (2008). O enfraquecimento e a ruptura dos vínculos sociais: uma dimensão essencial do processo de desqualificação social. In B. B. Sawaia (Org.), As artimanhas da exclusão: análise psicossocial e ética da desigualdade social (8ª ed.). Petrópolis, RJ: Vozes.

Santos, P. H. F. (2010). "Deus lhe pague": a condição servente na construção civil. Dissertação de Mestrado, Programa de Pós-Graduação em Psicologia, Universidade Federal de Minas Gerais, Belo Horizonte. Disponível em: http://www.bibliotecadigital.ufmg.br

Schwartz, Y. (2007). A dimensão coletiva do trabalho e as Entidades Coletivas Relativamente Pertinentes (ECRP). In Y. Schwartz \& L. Durrive, (Orgs.), Trabalho $\mathcal{E}$ ergologia: conversas sobre a atividade humana (pp. 151166). Niterói: UFF.

Schwartz, Y., Durrive, L. \& Duc, M. (2007a). Trabalho e ergologia. In Y. Schwartz \& L. Durrive, (Orgs.), Trabalho Ė ergologia: conversas sobre a atividade humana (pp. 25-36). Niterói: UFF.

Schwartz, Y., Durrive, L. \& Duc, M. (2007b). Técnicas e competências. In Y. Schwartz \& L. Durrive, (Orgs.), Trabalho $\mathcal{E}$ ergologia: conversas sobre a atividade humana (pp. 85-102). Niterói: UFF.

Schwartz, Y., Durrive, L. \& Duc, M. (2007c). Trabalho e uso de si. In Y. Schwartz \& L. Durrive, (Orgs.), Trabalho Ë ergologia: conversas sobre a atividade humana (pp. 191-223). Niterói: UFF. 
Schwartz, Y. \& Durive, L. (2009). L'activité en dialogues entretiens sur l'activité humaine (II). Toulouse: Octarés.

Silva, F. B. O. (2006). A relação entre o uso do álcool e o trabalho na construção civil. Dissertação de Mestrado, Programa de Pós-Graduação em Psicologia, Universidade Federal de Minas Gerais, Belo Horizonte.

Sousa, N. H. B. (1983). Construtores de Brasília. Petrópolis: Vozes.

Vieira, C. E. C. (2008). Assédio: do moral ao psicossocial. Curitiba: Juruá.

\section{Endereço para correspondência}

ph.faleiro@gmail.com, vanessa.abarros@gmail.com

Recebido em: 14/10/2010

Revisado em: 23/05/2011

Aprovado em: 11/06/2011 